\title{
In Situ Hybridization Analysis of Invasive Breast Carcinomas with Immunohistochemically Negative Her-2 Status (A National Multicenter Study)
}

\author{
Her-2 Durumu İmmünohistokimya ile Negatif olan İnvaziv Meme \\ Karsinomlarında İn Situ Hibridizasyon Yöntemi ile Değerlendirme \\ (Ulusal Çok Merkezli Çalışma)
}

\author{
Sıtkı TUZLALI', Ekrem YAVUZ' ${ }^{1}$, Tülay CANDA², Merih GÜRAY², Melin Özgün GEÇER ${ }^{3}$, Yurdanur SÜLLÜ4, \\ Cem SEZER ${ }^{5}$, Dinç SÜREN ${ }^{5}$, Serpil DiZBAY SAK ${ }^{6}$, Zerrin CALAY ${ }^{7}$, Şennur ILVAN ${ }^{7}$, Suzan ZORLUDEMIR ${ }^{8}$, \\ Melek ERGi ${ }^{8}$, Fatma Şeyda KARAVELiं ${ }^{9}$, Elif PEŞTERELI ${ }^{9}$, Fatih ÖZDENER ${ }^{10}$, Kasım ÜSTÜNDAĞ ${ }^{10}$
}

Departments of Pathology, 'istanbul University, Istanbul Faculty of Medicine, ISTANBUL, TURKEY, ${ }^{2}$ Dokuz Eylül University, Faculty of Medicine, IZMiR, TURKEY, ${ }^{3}$ Lütfi KIrdar Kartal Training and Research Hospital, ISTANBUL,TURKEY, ${ }^{4}$ Ondokuz Mayıs University, Faculty of Medicine, SAMSUN, TURKEY, ${ }^{5}$ Antalya Training and Research Hospital, ANTALYA, TURKEY, ${ }^{\circ}$ Ankara University, Faculty of Medicine, ANKARA, TURKEY, ${ }^{7}$ istanbul University, Cerrahpaşa Faculty of Medicine, isTANBUL, TURKEY, ${ }^{8}$ Çukurova University, Faculty of Medicine, ADANA, TURKEY, ${ }^{9}$ Akdeniz University, Faculty of Medicine, ANTALYA, TURKEY,

${ }^{10}$ Roche Müstahzarlari San. A.S., TURKEY

\section{ABSTRACT}

Objective: The aim of this study was to determine the rate of Her-2 gene amplification in breast cancer cases with a previous negative Her-2 result as determined by immunohistochemistry (score 0 or 1 ).

Material and Method: 552 cases of invasive breast carcinoma were assessed with the contribution of 9 centers. Previous immunohistochemistry score was either 0 or $1+$ in all cases. These cases were re-tested by Her-2 silver in situ hybridization in the central laboratory. Her-2 gene amplification was defined as Her-2/CEP 17 ratio of more than 2.2. Cases with a ratio between 1.8 and 2.0 were defined as equivocal and cases with a ratio of less than 1.8 were defined as negative.

Results: Re-testing of the 552 cases with silver in situ hybridization showed a total of 22 cases with Her- 2 gene amplification, of which $11(3.2 \%)$ were found to be score 0 , and 11 were found to be score $1+(5.3 \%)$ by immunohistochemistry previously. Her-2 gene amplification rate of cases (score 0 and $1+$ ) ranged from $0 \%$ to $10.48 \%$ among the centers. Polysomy was found in $28(8.1 \%)$ of the score 0 cases and $25(12.1 \%)$ among the score $1+$ cases. Five $(9.4 \%)$ of the cases with polysomy were found to be amplified, and 48 (90.6\%) were not.

Conclusion: The results of the study show that a group of cases (3.98\%) with a potential to benefit from anti-Her-2 therapy may be missed with the immunohistochemical method. This indicates the importance of quality assurance, especially in central laboratories with many breast cancer cases in daily practice.

Key Words: In situ hybridization, Immunohistochemistry, Breast neoplasms, Her-2, Quality assurance

(Turk Patoloji Derg 2014, 30:87-93)

Received : 06.02.2014 Accepted : 16.04.2014
ÖZ

Amaç: Bu çalışmada, Her-2 durumları̈önceden immünohistokimyasal olarak skor 0 veya $1+$ olarak tanımlanmış meme karsinomu olgularında silver in situ hibridizasyon ile tekrar test yapılarak Her-2 pozitiflik oranının tespit edilmesi amaçlanmıştır.

Gereç ve Yöntem: Çalışmada 9 merkezin katkısıyla, 552 olgu değerlendirildi. Çalışmaya, Her-2 immünohistokimya sonucu $0 / 1+$ bulunmuş meme kanseri olguları alındı. Bu olgulara ait parafin blok kesitlerinde merkez laboratuvarında Her-2 durumu silver in situ hibridizasyon yöntemiyle yeniden değerlendirildi. Her-2 gen amplifikasyonu, Her-2/ CEP 17 oranının 2,2'den fazla olması şeklinde tanımland1. Her-2/CEP 17 oranı 1,8-2,0 arasındaki olgular şüpheli ve 1,8 'in altındaki olgular ise negatif olarak değerlendirildi.

Bulgular: 552 olgunun in situ hibridizasyon ile tekrar değerlendirmesinde skor 0 olan olguların 11'i $(\% 3,2)$ ve skor $1+$ olanların 11'i $(\% 5,3)$ olmak üzere toplam 22 olguda Her-2 gen amplifikasyonu saptand. Skor 0 ve $1+$ olan olgulardaki Her-2 gen amplifikasyon saptama oranları çalışma merkezlerinde $\% 0$ ile $\% 10,48$ arasında değişmekteydi. Skor 0 olan olguların 28 'inde $(\% 8,1)$ ve skor 1+ olan olguların 25 'inde $(\% 12,1)$ polizomi görüldü. Polizomi olan olgulardan 5 'inde $(\% 9,4)$ Her-2 gen amplifikasyonu olduğu, 48'inde ise $(\% 90,6)$ olmadığı belirlendi.

Sonuç: Çalışmanın bulguları, anti- Her-2 tedaviden yararlanma potansiyeli olan bir popülasyonun $(\% 3,98)$ immünohistokimya yöntemi ile gözden kaçabileceğini göstermektedir. $\mathrm{Bu}$ sonuç, özellikle de çok sayıda meme kanseri olgusuyla karşılaşılan merkezi laboratuvarlarda kalite güvencesinin önemini ortaya koymaktadır.

Anahtar Sözcükler: İn situ hibridizasyon, İmmünohistokimya, Meme kanseri, Her-2, Kalite güvencesi

Correspondence: Sitkı TUZLALI

Tuzlalı Patoloji Laboratuvarı, Valikonağı Cd. Sezai Selek Sk. Sevim Apt. No. 7 D. 1 Teşvikiye, Şişli / İSTANBUL, TURKEY

E-mail: stuzlali@hotmail.com Phone: +90 2122968645 


\section{INTRODUCTION}

Overexpression/amplification of Her-2 has a great clinical importance since its presence is a necessity in selecting the patients for targeted therapy with trastuzumab. The appropriate selection of the patients depends on the accurate assessment of the presence or the absence of this receptor on the invasive breast cancer cells.

Most frequently used methods in determining Her-2 status are immunohistochemistry (IHC) and in situ hybridization (ISH). Using IHC, the overexpression of Her-2 receptor protein on the cell membrane is detected. ISH is regarded as the gold standard in determining Her-2 status and the principal is the assessment of the gene amplification. Some discordance exists between different laboratories after retesting the same cases with the same method $(1,2)$.

The aim of this study is to determine the rate of Her-2 positivity in samples with previously defined Her-2 status as IHC score 0 or $1+$, by re-testing them using silver in situ hybridization (SISH) method.

\section{MATERIALS and METHOD}

In this multicenter, non-interventional study, 552 cases of invasive breast carcinoma with a negative IHC result (score 0/1+) for Her-2 from 9 centers in Turkey were included.
The samples belonged to women aged 18-75 years. Formaldehyde fixed paraffin-embedded (FFPE) samples of the patients, which were found to have a Her-2 IHC score $0 / 1+$ during their routine work-up in each center, were retested using SISH method. Participating centers sent their samples to the central laboratory to test for Her-2 SISH by sticking a label containing study and center number, sample code and sample number on the container where samples were kept. The details of the previous IHC procedures for each participating center are shown in Table I.

Central SISH testing was performed by using Ventana Benchmark LT (Ventana Medical Systems, Tucson, Az, USA) with its standard protocol. Evaluation of the SISH tests were performed by using the ASCO/CAP recommendations (3) and the screening of each case was performed by one of the authors (ST). In all positive cases, borderline cases and near-borderline, near -positive cases, re-evaluation and decision was made by two of the authors (ST, EY) together.

Her-2 gene amplification was defined as Her-2/CEP 17 ratio of more than 2.2. Cases with a ratio between 1.8-2.0 were defined as equivocal and cases with a ratio of less than 1.8 were defined as negative. We also used another cut-off ratio, in which the definition of ISH positivity is $\leq 2.0$, in order to get a more comprehensive analysis.

Table I: Details of immunohistochemical procedures previously performed by the participating centers

\begin{tabular}{|c|c|c|c|c|c|c|}
\hline $\begin{array}{c}\text { Center } \\
\text { No. }\end{array}$ & Primary antibody & Clone & Producer & Dilution & $\begin{array}{c}\text { Incubation } \\
\text { time }\end{array}$ & \begin{tabular}{|c|} 
Detection system \\
(all fully automated)
\end{tabular} \\
\hline 1 & $\begin{array}{c}\text { anti c-erbB-2/ } \\
\text { her2neu }\end{array}$ & $\begin{array}{l}\text { SP3 (rabbit } \\
\text { monoclonal) }\end{array}$ & Lab Vision Corp & $1: 100$ & $32 \mathrm{~min}$ & Ventana BenchMark \\
\hline 2 & $\begin{array}{c}\text { anti c-erbB-2/ } \\
\text { her2neu }\end{array}$ & $\begin{array}{l}\text { SP3 (rabbit } \\
\text { monoclonal) }\end{array}$ & Lab Vision Corp & $1: 100$ & $32 \mathrm{~min}$. & Ventana BenchMark \\
\hline 3 & $\begin{array}{c}\text { anti erbB2/HER2/ } \\
\text { neuAb-17 }\end{array}$ & $\begin{array}{c}\text { (mouse) } \\
\text { e24001+3B5 }\end{array}$ & Thermo Scientific & $\begin{array}{c}\text { Ready to } \\
\text { use }\end{array}$ & $30 \mathrm{~min}$. & Leica Bond \\
\hline 4 & $\begin{array}{l}\text { anti c-erbB-2/ } \\
\text { her2neu }\end{array}$ & $\begin{array}{c}\mathrm{e} 2-4001+3 \mathrm{~B} 5 \\
\text { (mouse monoclonal) }\end{array}$ & Neomarkers & $1: 100$ & $32 \mathrm{~min}$ & Ventana BenchMark \\
\hline 5 & $\begin{array}{l}\text { anti erbB2/HER2/ } \\
\text { neuAb-17 }\end{array}$ & $\begin{array}{c}\text { (mouse monoclonal) } \\
\text { e } 24001+3 B 5\end{array}$ & Thermo Scientific & $\begin{array}{c}\text { Ready to } \\
\text { use }\end{array}$ & $30 \mathrm{~min}$ & Ventana BenchMark \\
\hline 6 & $\begin{array}{c}\text { anti c-erbB2-2 / } \\
\text { her2/neu }\end{array}$ & $\begin{array}{l}\text { SP3 (rabbit } \\
\text { monoclonal) }\end{array}$ & Neomarkers & $1: 200$ & $40 \mathrm{~min}$. & DAKO autostainer \\
\hline 7 & $\begin{array}{l}\text { Anti-c-erb-B2 } \\
\text { (Hercept test) }\end{array}$ & K5204 (polyclonal) & DAKO & $\begin{array}{c}\text { Ready to } \\
\text { use }\end{array}$ & $32 \mathrm{~min}$ & Ventana BenchMark \\
\hline 8 & $\begin{array}{c}\text { Anti-human } \\
\text { c-erbB-2 } \\
\text { oncoprotein }\end{array}$ & $\begin{array}{l}\text { Polyclonal rabbit } \\
\text { Code A0485 }\end{array}$ & DAKO & $1: 600$ & $32 \mathrm{~min}$ & Ventana BenchMark \\
\hline 9 & $\begin{array}{l}\text { anti c-erb B2 } \\
\text { oncoprotein }\end{array}$ & $\begin{array}{l}\text { CB11 mouse } \\
\text { monoclonal }\end{array}$ & Novocastra & $1: 40$ & $30 \mathrm{~min}$ & Leica Bond \\
\hline
\end{tabular}




\section{RESULTS}

Of the 552 samples, $346(62.7 \%)$ were previously found as IHC score 0 and 206 (37.3\%) as IHC score $1+$ in 9 centers joining the study. According to SISH results, 11 of IHC score 0 samples $(3.2 \%)$ and 11 of IHC score $1+$ samples (5.3\%), in total 22 samples (3.98\%) were evaluated as SISH positive (Table II). The SISH positivity rates for IHC score 0 and $1+$ cases were slightly higher $(4.16 \%)$, when a cut-off $\geq$ 2.0 was used (Table III).

In general, 522 (94.5\%) of the IHC- negative (score 0 and 1) cases were found as SISH negative. Eight of them (1.45\%) were categorized in the equivocal category by SISH and $22(3.98 \%)$ were found as SISH positive (false-negative for IHC) (Table IV).

Rates of SISH positivity varied between 0 and $10.48 \%$ among the centers joining the study. It was found $0 \%$ in three of the 9 centers (Center 1, $0 \%$ in 99 cases, Center 2, $0 \%$ in 37 cases and Center 7, $0 \%$ in 35 cases). The highest SISH positivity rate was $10.48 \%$ (13 cases in 124$)$ for Center 6 (Tables V, VI).

In most (16 of 22) of the false-negative cases, IHC on the same block was performed by the participating centers. Reevaluation of the original slides was also performed. Details are given in Table VII. In 9 of the 16 cases (56\%) repeat IHC revealed a positive score of $3+$. Re-resting did not have any effect on the IHC score in 3 (18.7\%) of the 16 cases. In 4 cases (25\%) after re-testing the score was changed to score $2+$. In one case a shift from score $1+$ to $2+$ occurred in reevaluation of the original slide. Re-testing of the same case by IHC again revealed a score of $2+$.

Polysomy which is defined as the presence of 3 or more signals for the centromeric probe, was found in 28 of the 346 IHC score 0 cases $(8.1 \%)$ and 25 of the 206 IHC score $1+$ cases $(12.1 \%)$. Of the 53 polysomic cases, $5(9.4 \%)$ were SISH positive and $48(90.6 \%)$ were negative. In other words, 5 of the 22 SISH-positive cases (22.7\%), and 48 of the 519 SISH-negative cases $(9.25 \%)$ were polysomic.

\section{DISCUSSION}

Patients with tumors containing Her-2 gene amplification or protein overexpression are more likely to benefit from trastuzumab treatment alone or in combination with other therapies (4). The accuracy in determination of these patients is of major clinical importance. In clinical practice, IHC score of $3+$ is regarded as the proof of Her2 positivity and IHC score of 0 and $1+$ is regarded as the Her-2 negativity without any additional confirmatory tests. Usually, additional ISH test is performed in cases with an IHC score of 2+. In Turkey, this algorithm is mostly used in therapeutic approach to breast cancer cases. Her2 positive breast cancer cases, either with IHC or ISH, are regarded as eligible for trastuzumab therapy by both social security administration and private insurance companies.

Table II: Distribution of the cases according to their SISH status

\begin{tabular}{|c|c|c|c|}
\hline IHC Result & $\begin{array}{c}\text { SISH Negative (0-1.79) } \\
\text { No. Cases (Percentage) }\end{array}$ & $\begin{array}{c}\text { SISH Equivocal (1.8-2.19) } \\
\text { No. Cases (Percentage) }\end{array}$ & $\begin{array}{c}\text { SISH positive ( } \geq 2.2) \\
\text { No. Cases (Percentage) }\end{array}$ \\
\hline 0 & $330(95.4 \%)$ & $5(\% 1.4)$ & $11(\% 3.2)$ \\
\hline+1 & $192(93.2 \%)$ & $3(\% 1.5)$ & $11(\% 5.3)$ \\
\hline
\end{tabular}

Table III: SISH status of the cases when $\geq 2.0$ is used as the cut off

\begin{tabular}{|c|c|c|}
\hline IHC Result & $\begin{array}{c}\text { SISH Negative (0- 1.99) } \\
\text { No. Cases (Percentage) }\end{array}$ & $\begin{array}{c}\text { SISH Positive ( } \geq 2.0) \\
\text { No. Cases (Percentage) }\end{array}$ \\
\hline 0 & $335(\% 96.8)$ & $11(\% 3.2)$ \\
\hline+1 & $194(\% 94.2)$ & $12(\% 5.8)$ \\
\hline
\end{tabular}

Table IV: SISH status of the all IHC- negative (score 0 and 1) cases

\begin{tabular}{|c|c|c|c|}
\hline $\begin{array}{c}\text { IHC Result } \\
\mathbf{0} \text { and } \mathbf{1}\end{array}$ & $\begin{array}{c}\text { SISH Negative (0- 1.79) } \\
\text { No. Cases (Percentage) }\end{array}$ & $\begin{array}{c}\text { SISH Equivocal (1.8-2.19) } \\
\text { No. Cases (Percentage) }\end{array}$ & $\begin{array}{c}\text { SISH positive }(\geq 2.2) \\
\text { No. Cases (Percentage) }\end{array}$ \\
\hline 552 & $522(95.4 \%)$ & $8(\% 1.45)$ & $22(\% 3.98)$ \\
\hline
\end{tabular}


Table V: The distribution of SISH results according to the centers where the IHC analysis were performed. Cut off value for SISH is $>2.2$

\begin{tabular}{|c|r|r|c|}
\hline \multirow{2}{*}{ Centers } & IHC score 0 and 1+ & $\begin{array}{c}\text { SISH negative } \\
\text { No. Cases (\%) }\end{array}$ & $\begin{array}{c}\text { SISH positive } \\
\text { No. Cases (\%) }\end{array}$ \\
\hline \multirow{2}{*}{1} & 0 & $77(\% 100.0)$ & $0(\% 0.0)$ \\
\cline { 2 - 4 } & +1 & $22(\% 100.0)$ & $0(\% 0.0)$ \\
\hline \multirow{2}{*}{2} & 0 & $19(\% 100.0)$ & $0(\% 0.0)$ \\
\cline { 2 - 4 } & +1 & $18(\% 100.0)$ & $0(\% 0.0)$ \\
\cline { 2 - 4 } & 0 & $30(\% 96.8)$ & $1(\% 3.2)$ \\
\hline \multirow{2}{*}{4} & +1 & $38(\% 95.0)$ & $0(\% 0.0)$ \\
\cline { 2 - 4 } & 0 & $33(\% 100.0)$ & $1(\% 8.3)$ \\
\hline \multirow{2}{*}{5} & +1 & $11(\% 91.7)$ & $1(\% 4.2)$ \\
\cline { 2 - 4 } & 0 & $23(\% 95.8)$ & $7(\% 8.3)$ \\
\cline { 2 - 4 } & +1 & $73(\% 97.7)$ & $6(\% 15.0)$ \\
\hline \multirow{2}{*}{6} & 0 & $34(\% 85.0)$ & $0(\% 0.0)$ \\
\cline { 2 - 4 } & +1 & $29(\% 100.0)$ & $0(\% 0.0)$ \\
\hline \multirow{2}{*}{8} & 0 & $6(\% 100.0)$ & $1(\% 5.9)$ \\
\cline { 2 - 4 } & +1 & $16(\% 94.1)$ & $1(\% 25.0)$ \\
\hline \multirow{2}{*}{9} & 0 & $3(\% 75.0)$ & $1(\% 3.1)$ \\
\cline { 2 - 4 } & +1 & $31(\% 96.9)$ & $0(\% 0.0)$ \\
\hline
\end{tabular}

Table VI: False negativity rates of IHC for each center

\begin{tabular}{|c|c|c|}
\hline Centers & Number of cases & False negativity \\
\hline 1 & 99 & $0(0 \%)$ \\
\hline 2 & 37 & $0(0 \%)$ \\
\hline 3 & 71 & $3(4.2 \%)$ \\
\hline 4 & 45 & $1(2.22 \%)$ \\
\hline 5 & 68 & $2(2.94 \%)$ \\
\hline 6 & 124 & $13(10.48 \%)$ \\
\hline 7 & 35 & $0(0 \%)$ \\
\hline 8 & 21 & $2(9.52 \%)$ \\
\hline 9 & 52 & $1(1.92 \%)$ \\
\hline
\end{tabular}

In this multicenter study, we tried to find the range of false negativity rates while making a decision for the Her-2 status using only an IHC test.

The frequency of Her-2 positivity is around $15-25 \%(3,4)$. In a previous multicenter study, among 753 invasive breast cancer patients from 5 centers in Turkey, Her-2 positivity was found to be $18.4 \%$ (5). This rate is comparable to those given in the literature (6-9). Yaziji et al. (9) found an 18\% rate of Her-2 positivity in a series of 2913 patients.
In this study, re-testing of the materials of the attending centers, which used their own methodology in assessing the Her -2 status, was performed using the SISH method. All of the centers used automatized IHC procedures with their own primary antibody and antigen retrieval process choices in their routine practice.

Analysis of concordance between a local and a highvolume central laboratory in a phase IV trial also showed poor concordance of IHC results, and concluded that Her-2 testing is most accurate when performed at a high-volume central laboratory (10). Laboratories attending this study are high-volume laboratories.

In designing our study, we didn't make any restrictions in the selection of methods - the antibodies, incubation times, mode of antigen retrieval process e.g. reflecting the "real life" procedures. We aimed to see the concordance of IHC results of these laboratories with a central SISH testing, which is regarded as the gold standard.

The mean value for false negativity is $3.98 \%$ and comparable to literature data and within the limits suggested by the ASCO/CAP guideline (3). According to the guideline, laboratories are permitted to attain a 95\% concordance between the IHC and ISH. In our study, except the two 
Table VII: Re-evaluation of the original slides and re-testing of the same cases

\begin{tabular}{|c|c|c|c|c|}
\hline Center no. & Case no. & Original IHC score & Re-evaluation of the original IHC slide & IHC score after re-testing \\
\hline 3 & $96 x x-11$ & $1+$ & Not available & Not available \\
\hline 3 & $288 x x-10$ & $1+$ & Not available & Not available \\
\hline 3 & $256 \mathrm{xx}-10$ & 0 & Not available & Not available \\
\hline 4 & $159 \mathrm{xx}-10$ & $1+$ & $2+$ & $2+$ \\
\hline 5 & $102 \mathrm{xx}-11$ & 0 & 0 & $3+$ \\
\hline 5 & $153 \mathrm{xx}-10$ & $1+$ & +1 & 0 \\
\hline 6 & $266 x x-09$ & $1+$ & +1 & $3+$ \\
\hline 6 & $314 \mathrm{xx}-10$ & $1+$ & $1+$ & $1+$ \\
\hline 6 & $200 \mathrm{xx}-10$ & $1+$ & $1+$ & $2+$ \\
\hline 6 & $67 x x-08$ & $1+$ & $1+$ & $3+$ \\
\hline 6 & $331 x x-08$ & 0 & 0 & $3+$ \\
\hline 6 & $310 x x-08$ & 0 & Not available & Not available \\
\hline 6 & $320 x x-08$ & 0 & 0 & $3+$ \\
\hline 6 & $231 x x-07$ & $1+$ & $1+$ & $3+$ \\
\hline 6 & $120 x x-07$ & 0 & 0 & $2+$ \\
\hline 6 & $223 x x-07$ & 0 & 0 & $2+$ \\
\hline 6 & $225 x x-06$ & 0 & 0 & $3+$ \\
\hline 6 & $225 x x-10$ & 0 & 0 & $1+$ \\
\hline 6 & $234 x x-11$ & $1+$ & $1+$ & $3+$ \\
\hline 8 & $44 x x-06$ & 0 & Not available & Not available \\
\hline 8 & $34 x x-05$ & $1+$ & Not available & Not available \\
\hline 9 & $136 x x-09$ & 0 & 0 & $3+$ \\
\hline
\end{tabular}

of the centers, false negativity rate was found to be within these limits, with three centers reaching the ideal rate of $0 \%$.

In a review of the literature, $63-100 \%$ of $3+$ cases, 12 $57 \%$ of $2+$ cases and $0-15 \%$ of $0 / 1+$ cases showed gene amplification as determined by FISH (11). Generally, the discordance rates for $0 / 1+$ cases in the literature vary between 2-8\% (12). Concordance rates between reference/ central laboratories are much better than the concordance rates between the local and reference laboratories. In UK reference laboratories, only $0.7 \%$ of the IHC (-) cases showed gene amplification (13).

Rates of SISH positivity varied between 0 and $10.48 \%$ in our study. The false negativity rates for centers 6 and 8 , which are dealing with high-volume breast cancer patients, seemed high (10.48\% and 9.52\%). There may be a defect in any step of their IHC procedure at least in the period in which cases are reserved for this study. In a study with 6556 cases, Owens et al. (7) using the 2.2 as cut off point, found that $1.8 \%$ of the cases with score 0 and $5.1 \%$ of the score $1+$ cases were FISH positive. Pauletti et al (14) found that $21 \%$ of the 900 cases were positive by FISH, and $17.2 \%$ of the 856 of these samples were positive by IHC. They concluded that the discrepancy was consistent with the expected loss of IHC sensitivity, associated with tissue fixation/ embedding. The mean false negativity rate in our study is similar to Pauletti's study, with two of the laboratories with unacceptable rates. Yaziji et al (9) found a high concordance (97.2 \%) between IHC and FISH testing in 2933 cases. The same group in their later study found a concordance rate of over $99 \%$ (15).

In this study, participating centers re-evaluated the original IHC slides themselves in 16 of the 22 false-negative cases. Scoring was changed only in one case (about 6\%). This means that analytic causes played a minor role in false negativity. Nine $(56 \%)$ of the false-negative cases were rescored as $3+$ and $4(25 \%)$ of them as $2+$. In over $80 \%$ of the false-negative cases, pre-analytical procedures adversely affected the result.

Reported frequencies of polysomy ranges from 5\% to 50\% depending on the study population and the definition of 
polysomy $17(16,17)$. In our study we found polysomy in $28(8.1 \%)$ of the score 0 cases and $25(12.1 \%)$ of the score $1+$ cases, using the definition of polysomy as 3 or more signals detected in SISH. This frequency is near the lower end of the spectrum given above. However, it is also known that the frequency of polysomy is higher in $2+$ and $3+$ cases compared to IHC negative cases. Our results are comparable to Hyun et al. (18) who found polysomy in $12.3 \%$ of their IHC negative cases. There are conflicting findings about the "unamplified polysomy" cases, stating that they are associated with poor prognostic parameters (16) or not (19). Most of the cases (90.5\%) with polysomy were found to be associated with unamplified cases in our study.

During our final revision of this article before submission, the early online release of 2013 update on ASCO/CAP guideline appeared (20). According to this guideline, Her-2 positivity for SISH is accepted as the Her-2/CEP 17 ratio of $\geq 2$, whereas Her-2/CEP 17 ratio of $<2$ as negative. Our results according to this threshold were already given in Table II. Twenty-three of our cases (4.1\%) were SISH positive according to this update.

The results of this study show us the importance of internal and external quality assurance procedures. This begins with every laboratory's periodical checking of their positivity rates. In our previous study we found the frequency of IHC positivity as $18.4 \%$ in Turkey (5). If the results of a laboratory are too low or too high as compared to this frequency, this means that some problem exists regarding tissue fixation, antigen retrieval, the antibody used, incubation time and evaluation procedure as well. Her-2 rates below 10\% cannot be explained by biological factors such as ethnicity (21). Internal and external quality assurance is an essential component of obtaining accurate and consistent diagnostic results.

As stated by the ASCO/CAP guideline "the upper limit of $5 \%$ false-negatives should be considered high in view of the curative potential of trastuzumab treatment in the adjuvant setting, and laboratories should aim at bringing this percentage of false- negative tests as close to $0 \%$ as possible" (3).

A second issue to be discussed is the use of the ISH test as the first step in evaluation of Her-2 status, since a percentage of Her-2 positive cases that cannot be detected by IHC are detected by the ISH method. IHC is mostly dependent on the quality of membranous staining that is more easily affected by fixation, handling and antibody choice. ISH is significantly less dependent on tissue fixation methods, making this assay more reproducible between central and peripheral laboratories than IHC (12). ISH on the other hand is time-consuming and expensive when compared to IHC. Whatever method is used, self-control by quality assurance is necessary. IHC may be better used as the first step after reaching a high rate of IHC-ISH concordance (9).

In conclusion, there was an acceptable mean percentage of false negative IHC cases in our study, with some laboratories with unacceptable values and some with ideal rates that is $0 \%$. This study also revealed the necessity of quality assurance even in central laboratories dealing with a high number of breast cancer cases.

\section{CONFLICT OF INTEREST}

This study was funded by Roche Müstahzarları Sanayi A.Ş.

\section{REFERENCES}

1. Bilous M, Ades C, Armes J, Bishop J, Brown R, Cooke B, Cummings M, Farshid G, Field A, Morey A, McKenzie P, Raymond W, Robbins P, Tan L. Predicting the HER2 status of breast cancer from basic histopathology data: An analysis of 1500 breast cancers as part of the HER2000 international study. Breast. 2003;12:92-8.

2. Perez EA, Roche PC, Jenkins RB, Reynolds CA, Halling KC, Ingle JN, Wold LE. HER2 testing in patients with breast cancer: Poor correlation between weak positivity by immunohistochemistry and gene amplification by fluorescence in situ hybridization. Mayo Clin Proc. 2002;77:148-54.

3. Wolff AC, Hammond ME, Schwartz JN, Hagerty KL, Allred DC, Cote RJ, Dowsett M, Fitzgibbons PL, Hanna WM, Langer A, McShane LM, Paik S, Pegram MD, Perez EA, Press MF, Rhodes A, Sturgeon C, Taube SE, Tubbs R, Vance GH, van de Vijver M, Wheeler TM, Hayes DF. American Society of Clinical Oncology/College of American Pathologists: American Society of Clinical Oncology/College of American Pathologists guideline recommendations for human epidermal growth factor receptor 2 testing in breast cancer. Arch Path Lab Med. 2007;131:18-43.

4. Slamon DJ, Clark GM, Wong SG, Levin WJ, Ullrich A, McGuire WL. Human breast cancer: Correlation of relapse and survival with amplification of the HER-2/neu oncogene. Science. 1987;235:177-82.

5. Tuzlalı S, Yavuz E, Canda T, Özgün Geçer M, Süllü Y, Sezer C, Süren D, Dizbay Sak S, Calay Z, İlvan Ş, Zorludemir S, Ergin M, Karaveli FŞ, Peştereli E, Özdener F, Üstündağ K. Meme kanserinde aşırı HER 2 reseptörü ekspresyonunun değerlendirildiği ulusal çok merkezli epidemiyolojik çalışma. 21.Ulusal Patoloji Kongresi Bildiri Özetleri; 2011 Kasım 16-21; İzmir, Türkiye

6. Lund MJ, Butler EN, Hair BY, Ward KC, Andrews JH, OpreaIlies G, Bayakly AR, O'Regan RM, Vertino PM, Eley JW. Age/ race differences in HER2 testing and in incidence rates for breast cancer triple subtypes. A population-based study and first report. Cancer. 2010;116:2549-59. 
7. Owens MA, Horten BC, Da Silva MM. HER2 amplification ratios by fluorescence in situ hybridization and correlation with immunohistochemistry in a cohort of 6556 breast cancer tissues. Clin Breast Cancer. 2004;5:63-9.

8. Penault-Llorca F, Bilous M, Dowsett M, Hanna W, Osamura RY, Rüschoff J, van de Vijver M. Emerging technologies for assessing HER2 amplification. Am J Clin Pathol. 2009;132:539-48.

9. Yaziji H, Goldstein LC, Barry TS, Werling R, Hwang H, Ellis GK, Gralow JR, Livingston RB, Gown AM. HER-2 testing in breast cancer using parallel tissue-based methods. JAMA. 2004;291:1972-7.

10. Reddy JC, Reimann JD, Anderson SM, Klein PM. Concordance between central and local laboratory HER2 testing from a community-based clinical study. Clin Breast Cancer. 2006;7: 153-7.

11. Dendukuri N, Khetani K, McIsaac M, Brophy J. Testing for HER2positive breast cancer: A systematic review and cost-effectiveness analysis. CMAJ. 2007;176:1429-34

12. Sauter G, Lee J, Bartlett JM, Slamon DJ, Press MF. Guidelines for human epidermal growth factor receptor 2 testing: Biologic and methodologic considerations. J Clin Oncol. 2009;27:1323-33.

13. Walker RA, Bartlett JM, Dowsett M, Ellis IO, Hanby AM, Jasani B, Miller K, Pinder SE. HER2 testing in the UK: Further update to recommendations. J Clin Pathol. 2008;61:818-24.

14. Pauletti G, Dandekar S, Rong H, Ramos L, Peng H, Seshadri R, Slamon DJ. Assessment of methods for tissue-based detection of the HER-2/neu alteration in human breast cancer: A direct comparison of fluorescence in situ hybridization and immunohistochemistry. J Clin Oncol. 2000;18:3651-64.

15. Gown AM, Goldstein LC, Barry TS, Kussick SJ, Kandalaft PL, Kim PM, Tse CC: High concordance between immunohistochemistry and fluorescence in situ hybridization testing for HER2 status in breast cancer requires a normalized IHC scoring system. Mod Pathol. 2008;21:1271-7.
16. Krishnamurti U, Hammers JL, Atem FD, Storto PD, Silverman JF. Poor prognostic significance of unamplified chromosome 17 polysomy in invasive breast carcinoma. Mod Pathol. 2009;22:1044-8.

17. Vanden Bempt I, Van Loo P, Drijkoningen M, Neven P, Smeets A, Christiaens MR, Paridaens R, De Wolf-Peeters C. Polysomy 17 in breast cancer: Clinicopathologic significance and impact on HER-2 testing. J Clin Oncol. 2008;26:4869-74.

18. Hyun CL, Lee HE, Kim KS, Kim SW, Kim JH, Choe G, Park SY. The effect of chromosome 17 polysomy on HER-2/neu status in breast cancer. J Clin Pathol. 2008;61:317-21.

19. Torrisi R, Rotmensz N, Bagnardi V, Viale G, Curto BD, Dell'orto P, Veronesi P, Luini A, D’Alessandro C, Cardillo A, Goldhirsch A, Colleoni M. HER2 status in early breast cancer: Relevance of cell staining patterns, gene amplification and polysomy 17. Eur J Cancer. 2007;43:2339-44.

20. Wolff AC, Hammond ME, Hicks DG, Dowsett M, McShane LM, Allison KH, Allred DC, Bartlett JM, Bilous M, Fitzgibbons P, Hanna W, Jenkins RB, Mangu PB, Paik S, Perez EA, Press MF, Spears PA, Vance GH, Viale G, Hayes DF. American Society of Clinical Oncology; College of American Pathologists: Recommendations for human epidermal growth factor receptor 2 testing in breast cancer: American Society of Clinical Oncology/ College of American Pathologists clinical practice guideline update. J Clin Oncol. 2013;31:3997-4013.

21. Ross JS. Saving lives with accurate HER2 testing. Am J Clin Pathol. 2010;134:183-4. 